\title{
Epichlorohydrine crosslinked chitosan cinnamaldehyde Schiff base: Synthesis, characterization, thermal studies and its application in adsorption of methyl green
}

\section{Zahra Bashandeh}

Faculty of Science, Golestan University

Aliakbar Dehno Khalaji ( $\sim$ alidkhalaji@yahoo.com )

Faculty of Science, Golestan University

\section{Research Article}

Keywords: Epichlorohydrine, Crosslinked, Chitosan cinnamaldehyde, Schiff base, Removal

Posted Date: March 10th, 2021

DOI: https://doi.org/10.21203/rs.3.rs-291722/v1

License: (c) (1) This work is licensed under a Creative Commons Attribution 4.0 International License. Read Full License 


\section{Abstract}

Epichlorohydrine crosslinked chitosan cinnamaldehyde Schiff base (Epy-Chit-cin) had been synthesized by the reaction of epichlorohydrine, chitosan and trans-cinnamaldehyde (weight ratio 1:1:1) and characterized by FT-IR, UV-Vis, TG-DTA, DSC and XRD. The efficiency of the prepared Epy-Chit-cin was studied for the methyl green (MG) dye removal from aqueous solutions. The effects of $\mathrm{pH}$, adsorbent dosage and contact time on the adsorption process were evaluated. Results showed that the equilibrium of MG adsorption by Epy-Chit-cin was reached at 120 min contact time and the maximum adsorption capacity obtained 98.47 at the presence of $0.02 \mathrm{~g}$ of Epy-Chit-cin.

\section{Introduction}

Pollution by various organic dyes [1-4] and heavy metal ions [5-6] is a great threat for human health and environment due to their stability, toxicity, non-biodegradability. Most of organic dyes are cheap, very easy to obtain, more stable (not easily decomposed under natural conditions) and widely used to color products in various industries such as textiles, leather and plastics [1-4]. These organic days can damages the balance of the ecosystem [2]. Therefore, remove of them from wastewaters is necessary. Until now, various techniques have been reported for remove of various dyes such as biological degradation [7], oxidation [8] chemical coagulation and adsorption [1-4, 9-14]. Chitosan, as a natural polymer, is harmless to humans [3], eco-friendly, nontoxic and also not expensive [2]. Due to containing many amine and hydroxyl groups on chitosan and its derivatives, they used as a good adsorbent for remove of various dyes [2-5, 11-14]. Rahmi et al. [2] reported the maximum adsorption capacity of $20.408 \mathrm{mg} / \mathrm{g}$ for the methylene blue removal using $\mathrm{H}_{2} \mathrm{SO}_{4}$ crosslinked magnetic chitosan nanocomposite beads. Cinar et al. [4] prepared nano-ZnO/chitosan composite beads as an efficient removal of RB5. The maximum adsorption capacity has been found to be $189.44 \mathrm{mg} / \mathrm{g} . \mathrm{Ke}$ et al. [11] reported methyl green removal from wastewater using the modified chitosan by quaternary ammonium salt. We can modify chitosan using various crosslinking agents such as terephthaldehyde [15], glutaric acid [16] and epichlorohydrine [17], to improve its mechanical performance.

In this paper, an epichlorohydrine crosslinked chitosan cinnamaldehyde Schiff base (Epy-Chit-cin) (Scheme 1) was synthesized and used as adsorbent for removal of methyl green from aqueous solutions. The effects of $\mathrm{pH}$, dosage of Epy-Chit-cin and contact time on the adsorption of methyl green were discussed.

\section{Experimental}

\section{Materials and characterization techniques}

Chitosan, epichlorohydrine, trans-cinnamaldehyde, glacial acetic acid, and ethanol were purchased from Sigma-Aldrich and Merck Co. and were used as received without further purification. Perkin-Elmer FT-IR spectrophotometer was used for the recording FT-IR ( $\mathrm{KBr}$ disks, $\left.4000-400 \mathrm{~cm}^{-1}\right)$ spectrum. The Perkin- 
Elmer TG-DTA analyzer was used for the thermogravimetry analysis in air atmosphere at a flow rate of 20 ${ }^{\circ} \mathrm{C} / \mathrm{min}\left(25-825^{\circ} \mathrm{C}\right)$. DSC analysis of compounds was recording DSC analyzer Model 60A, Shimadzu, Japan. XRD patterns were determined by Bruker AXS-D8 X-ray diffractometer $\left(2 \theta=10-80^{\circ}\right)$, and SEM images were recorded on the TESCAN Vega Model scanning electron microscope. UV-Vis spectra were carried out with UV-Visible spectrophotometer (Perkin-Elmer).

\section{Synthesis of Epy-Chit-cin}

This compound was prepared based on the method mentioned in the literature [17] and with some modifications as follows. Chitosan $(2 \mathrm{~g})$ was suspended in $100 \mathrm{~mL}$ of ethanol-glacial acetic acid (95:5 $\mathrm{v} / \mathrm{v}$ ) and stirred at room temperature. After $10 \mathrm{~min}, 10 \mathrm{~mL}$ ethanolic solution of epichlorohydrine $(1 \mathrm{~mL})$ was slowly added and the reaction mixture was stirred at $80^{\circ} \mathrm{C}$ for $6 \mathrm{~h}$. Then, $10 \mathrm{~mL}$ ethanolic solution of trans-cinnamaldehyde $(2 \mathrm{~mL})$ was added and stirred for about $12 \mathrm{~h}$ at $80^{\circ} \mathrm{C}$, up to a pale yellow solid precipitated. The mixture was cooled and the solid was filtered off, washed with cold ethanol and dried at room temperature for several days.

\section{Adsorption experiments}

All adsorption experiments were carried out in a series of $50 \mathrm{~mL}$ Erlenmeyer flasks contain $20 \mathrm{~mL}$ of dye solution $(40 \mathrm{mg} / \mathrm{L})$ with a various dosage adsorbent. The effects of $\mathrm{pH}$ and contact times $(0-120 \mathrm{~min})$ were investigated. The solutions were the shaken and at various contact time, then adsorbent (Epy-Chitcin) was separated by centrifuged and the solution was analyzed by using UV-Vis spectrophotometer.

The remove rate $\mathrm{R}(\%)$ and adsorption capacity $\mathrm{q}(\mathrm{mg} / \mathrm{g})$ were calculated based on the experiments using formulas are listed as follows:

$$
R \%=\frac{C o-C t}{C o} \times 100
$$

Where $C_{\mathrm{o}}(\mathrm{mg} / \mathrm{L})$ is the initial concentration of $\mathrm{MG}$ and $C_{\mathrm{t}}(\mathrm{mg} / \mathrm{L})$ is the concentration of $\mathrm{MG}$ after adsorption.

\section{Results And Discussions}

\section{Characterization of Epy-Chit-cin}

The FT-IR spectrum of Epy-Chit-cin is shown in Fig. 1. As seen in Fig. 1, the peak appearing at $2861 \mathrm{~cm}^{-1}$ is assigned to the stretching of the $\mathrm{C}-\mathrm{H}$ bond $[3,11,18]$. The sharp peak at about 1632 is assigned to the $\mathrm{C}=\mathrm{N}$ iminic stretching band $[3,11,18]$. Two peaks appeared at about $1060 \mathrm{~cm}^{-1}$ is assigned to the $\mathrm{C}-\mathrm{O}-\mathrm{C}$ in the pyranose ring and the $\mathrm{C}-\mathrm{N}$ stretching band $[3,4]$. 
The UV-Vis spectrum of Epy-Chit-cin is shown in Fig. 2. The solubility of this compound is very low in all common organic solvents such as methanol, Ethanol, acetonitrile, chloroform, DMF and DMSO. As seen in Fig. 2, the UV-Vis spectrum has been recorded by dispersion of compound in the water by ultrasonic irradiation for $30 \mathrm{~min}$. A broad peak at $282 \mathrm{~nm}$ is assigned to the $n-\pi^{*}$ and $\pi-\pi^{*}$ in the aromatic and iminic groups of Epy-Chit-cin [18].

TG-DTA curves of Epy-Chit-cin are presented in Fig. 3. Epy-Chit-cin shows three degradation stages. This compound is stable until $75^{\circ} \mathrm{C}$. After that, in the first stage between temperature range $75-150{ }^{\circ} \mathrm{C}$, it show a little mass loss $(<5 \%)$ corresponds to moisture or ethanol molecules adsorbed on the surface of Epy-Chit-cin [19]. In the second stage, Epy-Chit-cin shows mass loss of $\approx 50 \%$ in the temperature range $150-400^{\circ} \mathrm{C}$ and is attributed to the thermal degradation of polymeric chain. This stage is exothermic and confirmed by DTA curve, while the first stage (evaporation of moisture or ethanol) is endothermic. In the third stage, there is a mass loss of $\approx 17 \%$ from 400 to $825^{\circ} \mathrm{C}$, due to the thermal degradation of residual crosslinked of the second stage [19].

DSC thermogram of Epy-Chit-cin shows in Fig. 4. There is a $\mathrm{n}$ endothermic peak around $84.5^{\circ} \mathrm{C}$ due to evaporation of moisture and ethanol molecules [18,20], while there is an exothermic peak at about 277.5 ${ }^{\circ} \mathrm{C}$ assigned to the its thermal degradation of polymeric chain $[18,20]$.

In the XRD pattern of Epy-Chit-cin (Fig. 5), there are two peaks at $11.29^{\circ}$ and $20.48^{\circ}$. Chitosan reveals a peak at about $10^{\circ}$ and $20^{\circ}[4,14]$. In this compound a peak appeared at about $11.29^{\circ}$ may be confirm the changes on the modified chitosan using epichlorohydrine and trans-cinnamaldehyde.

\section{Adsorption studies}

Methyl green is a cationic triphenylmethane dye and used for dyeing nylon, wool, silk and cotton in the textile industry [21] and as indicator dyes due to their $\mathrm{pH}$ sensitivity [22]. Then the $\mathrm{pH}$ of solution is one of the most important parameter in the adsorption process $[2,411,14]$. The maximum methyl green removal ( $353.33 \mathrm{mg} / \mathrm{g}$ ) was observed in the $\mathrm{pH}$ of 7 for activated bentonite [23] and $67.93 \mathrm{mg} / \mathrm{g}$ in the $\mathrm{pH}$ of $8 \mathrm{for}$ activate carbon [24]. The effect of initial $\mathrm{pH}$ on the removal percentage of $\mathrm{MG}$ was studied by varying the initial $\mathrm{pH}$ from 2 to 10 by adding a solution of $\mathrm{HCl}(0.1 \mathrm{M})$ or $\mathrm{NaOH}(0.1 \mathrm{M})$ and shown in Fig. 6 . The maximum methyl green removal (98.47\%) was observed in the $\mathrm{pH}$ of 8 , due to partial $\delta$ surface charge of Epy-Chit-cin. In this case, an electrostatic attraction occurs between this partial negative charge and the positive charge of methyl green. Therefore, the $\mathrm{pH}$ of 8 was used to investigate the effect of contact time and adsorbent amount on MG removal.

The percentage removal of MG solution at different contact times for various adsorbent dosages $(0.05$, 0.01 and $0.02 \mathrm{~g}$ ) are shown in Fig. 7. As seen in Fig. 7, the percentage removal of MG increased by increasing the adsorbent dosage. It is also seen that the percentage removal is much faster at the beginning of the reaction, due to the increase in adsorbent active sites on the surface of Epy-Chit-cin. Also, the percentage removal has been increased by increasing the contact time [24]. 


\section{Conclusions}

In this paper, the Epy-Chit-cin absorbent based on the chitosan as natural polymer was successfully prepared by reaction of chitosan, epichlorohydrine and trans-cinnamaldehyde and characterized by various techniques. The adsorption performance of Epy-Chit-cin on removal of MG from aqueous solutions was investigated. Results show that the Epy-Chit-cin as adsorbent can removed the MG from aqueous solution and the removal rate achieved was $98.47 \%$. These results show that the Epy-Chit-cin can be used as an environmentally friendly bio-adsorbent.

\section{Declarations}

\section{Conflict of interest}

The authors declare that there is no conflict of interest.

\section{Acknowledgments}

The authors acknowledge the Golestan University for supporting this work.

\section{References}

[1] G. Pandey, S. Singh, G. Hitkari, Synthesis and characterization of polyvinyl pyrrolidone (PVP)-coated Fe304 nanoparticles by chemical co-precipitation method and removal of Congo red dye by adsorption process, Int. Nano Lett. 8 (2018) 111-121.

[2] Rahmi, Ismaturrahmi, I. Mustafa, Methylene blue removal from water using $\mathrm{H}_{2} \mathrm{SO}_{4}$ crosslinked magnetic chitosan nanocomposite beads, Microchem. J. 144 (2019) 397-402.

[3] D. Yang, L. Qiu, Y. Yang, Efficient adsorption of methyl orange using a modified chitosan magnetic composite adsorbent, J. Chem. Eng. Data 61 (2016) 3933-3940.

[4] S. Cinar, U.H. Kaynar, T. Aydemir, S.C. Kaynar, M. Ayvacikli, An efficient removal of RB5 from aqueous solution by adsorption onto nano-ZnO/Chitosan composite beads, Int. J. Biol. Macromol. 96 (2017) 459465 .

[5] A. Razzaz, S. Ghorban, L. Hosayni, M. Irani, M. Aliabadi, Chitosan nanofibers functionalized by $\mathrm{TiO}_{2}$ nanoparticles for the removal of heavy metal ions, J. Taiwan Ins. Chem. Eng. 58 (2016) 333-343.

[6] A.H.A. Saad, A.M. Azzam, S.T. El-Wakeel, B.B. Mostafa, M.B. Abd El-latif, Removal of toxic metal ions from wastewater using ZnO@chitosan core-shell nanocomposite, Environ. Nanotech. Mon. Manag. 9 (2018) 67-75.

[7] M. Kornaros, G. Kyberatos, Biological treatment of wastewaters from a dye manufacturing company using a trickling filter, J. Haz. Mater. 136 (2006) 95-102. 
[8] K. Wang, J. Guo, M. Yang, H. Junji, R. Deng, Decomposition of two haloacetic acids in water using UV radiation, ozone and advanced oxidation processes. J. Haz. Mater. 162 (2009) 1243-1248.

[9] M.T. Yagub, T.K. Sen, S. Afroze, H.M. Ang, Dye and its removal from aqueous solution by adsorption: a review, Adv. Coll. Interface Sci. 209 (2014) 172-184.

[10] J. Wang, X. Shao, Q. Zhang, G. Tian, X. Ji, W. Bao, Preparation of mesoporous magnetic $\mathrm{Fe}_{2} \mathrm{O}_{3}$ nanoparticles and its application for organic dyes removal, J. Mol. liq. 248 (2017) 13-18.

[11] P. Ke, D. Zeng, K. Xu, J. Cui, X. Li, G. Wang, Preparation of quaternary ammonium salt-modified chitosan microspheres and their application in dyeing wastewater treatment, ACS Omega 5 (2020) 24700-24707.

[12] L. Zhai, Z. Bai, Y. Zhu, B. Wang, W. Luo, Fabrication of chitosan microsphere for efficient adsorption of methyl orange, Chin. J. Chem. Eng. 26 (2018) 657-666.

[13] M. Vakili, M. Rafatullah, B. Salamatinia, A.Z. Abdullah, M.Z. Ibrahim, K.B. Tan, Z. Gholami, P. Amouzegar, Application of chitosan and its derivatives as adsorbents for dye removal from water and wastewater: A review, Carbohydr. Polym. 113 (2014) 115-130.

[14] G. Yuvaraja, D.Y. Chen, J.L. Pathak, J. Long, M.V. Subbaiah, J.C. Wen, C.L. Pan, Preparation of novel aminated chitosan schiff's base derivative for the removal of methyl orange dye from aqueous environment and its biological applications, Int. J. Biol. Macromol. 146 (2020) 1100-1110.

[15] G. Yuvaraja, Y. Pang, D.Y. Chen, L.J. Kong, S. Mehmood, M.V. Subbaiah, D.S. Rao, C.M. Pavuluri, J.C. Wen, G.M. Reddy, Modification of chitosan macromolecule and its mechanism for the removal of $\mathrm{Pb}(\mathrm{II})$ ions from aqueous environment, Int. J. Biol. Macromol. 136 (2019) 177-188.

[16] G. Matinez-Mejia, N.A. Vazquez-Torres, A. Castell-Rodriguez, J.M. del Rio, M. Corea, R. JimenezJuarez, Synthesis of new chitosan-glutaraldehyde scaffolds for tissue engineering using Schiff reactions, Coll. Surf. A. 579 (2019) 123658.

[17] Y. Yan, G. Yuvaraja, C. Liu, L. Kong, K. Guo, G.M. Reddy, G.V. Zyryanov, Removal of Pb(II) ions from aqueous media using epichlorohydrin crosslinked chitosan Schiff's base@ $\mathrm{Fe}_{3} \mathrm{O}_{4}\left(\mathrm{ECCSB}_{\mathrm{FFe}} \mathrm{O}_{4}\right)$, Int. J. Biol. Macromol. 117 (2018) 1305-1313.

[18] T.M. Tamer, M.A. Hassan, A.M. Omer, W.M. Baset, M.E. Hassan, M.E.A. El-Shafeey, M.S. Mohy Eldin, Synthesis, characterization and antimicrobial evaluation of two aromatic chitosan Schiff base derivatives, Process Biochem. 5 (2016) 1721-1730.

[19] S. Lal, S. Arora, V. Kumar, S. Rani, C. Sharma, P. Kumar, Thermal and biological studies of Schiff bases of chitosan derived from heteroaryl aldehydes, J. Therm. Anal. Calorim. 132 (2018) 1707-1716. 
[20] M.A. Hassan, A.M. Omer, E. Abbas, W.M. Baset, T.M. Tamer, Preparation, physicochemical characterization and antimicrobial activities on novel two phenolic chitosan Schiff base derivatives, Sci. Rep. 8 (2018) 11416.

[21] W. Azmi, R.K. Sani, U.C. Banerjee, Biodegradation of triphenylmethane dyes. Enzyme Microb. Technol. 22 (1998) 185-191.

[22] C. Fleischmann, M. Lievenbrück, H. Ritter, Polymers and Dyes: Developments and Applications, Polymers 7 (2015) 717-746.

[23] A. Maghni, M. Ghelamallah, A. Benghalem, Sorptive removal of methyl green from aqueous solutions using activated bentonite, Acta Phys. Pol. A. 132 (2017) 448-450.

[24] K. Rida, K. Chaibeddra, K. Cheraitia, Adsorption of cationic dye methyl green from aqueous solution onto activated carbon prepared from Brachychiton Populneus fruit shell, Ind. J. Chem. Technol. 27 (2020) 51-59.

\section{Figures}

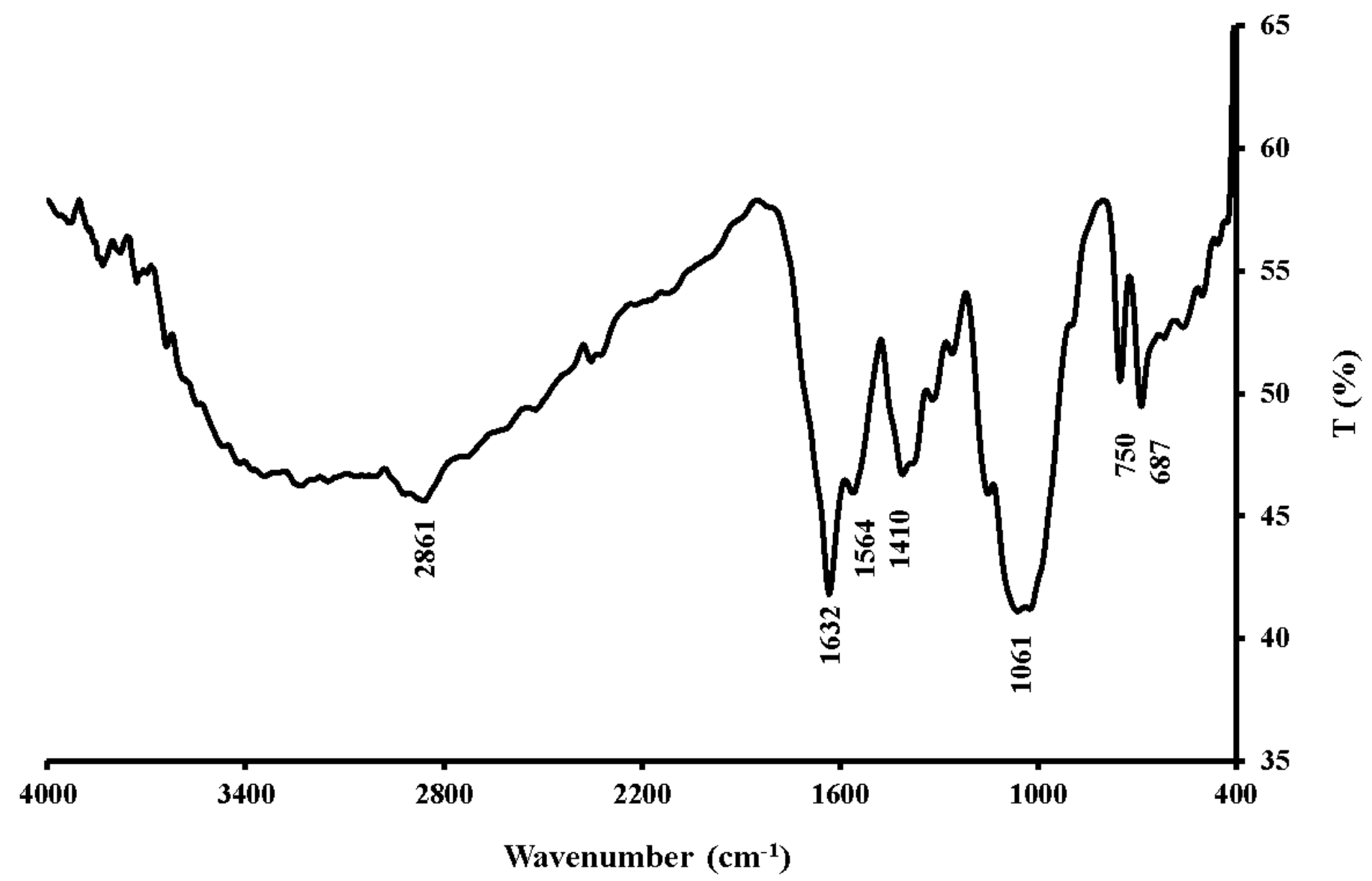


Figure 1

FT-IR spectrum of Epy-Chit-cin

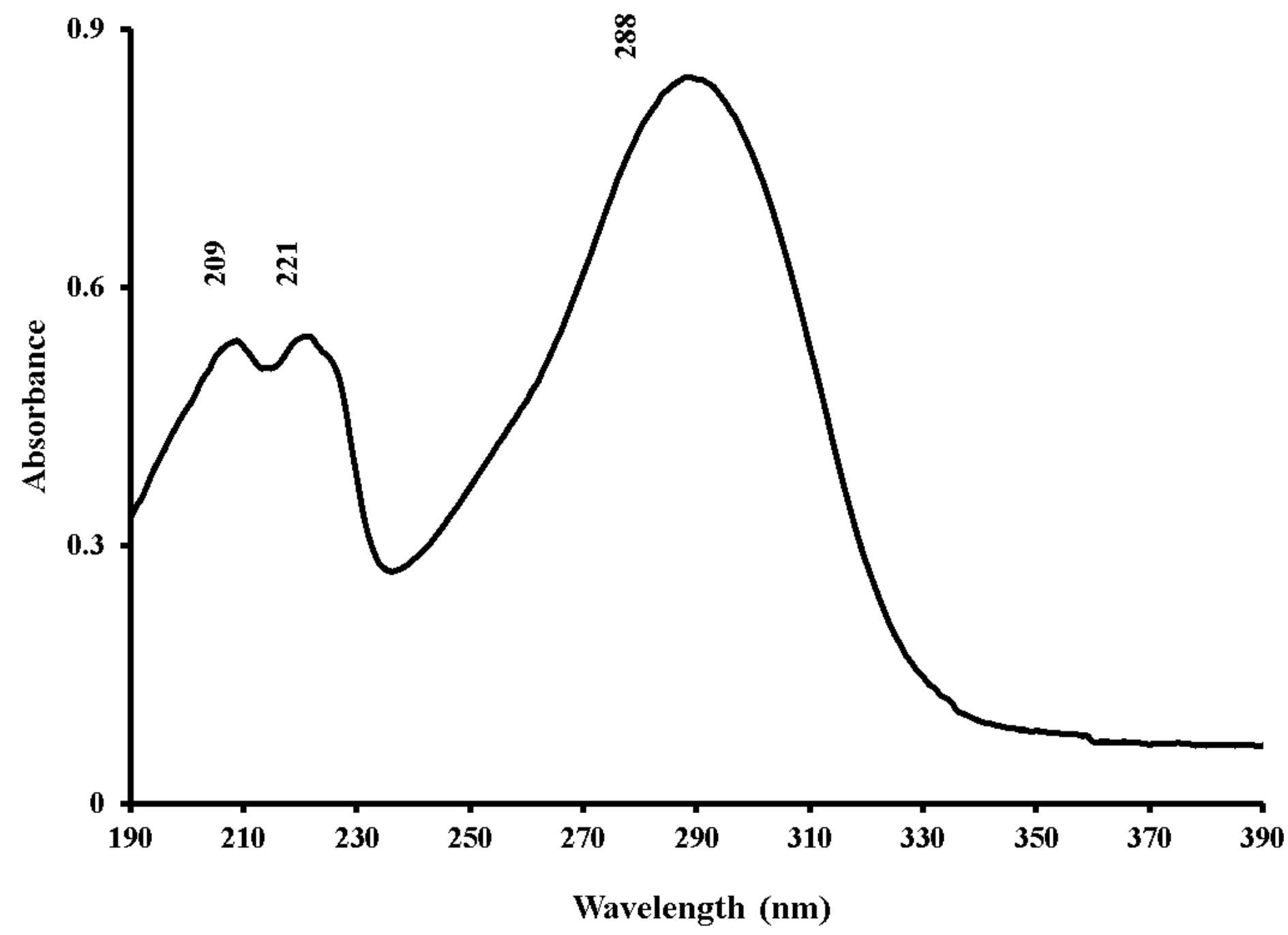

Figure 2

UV-Vis spectrum of Epy-Chit-cin 


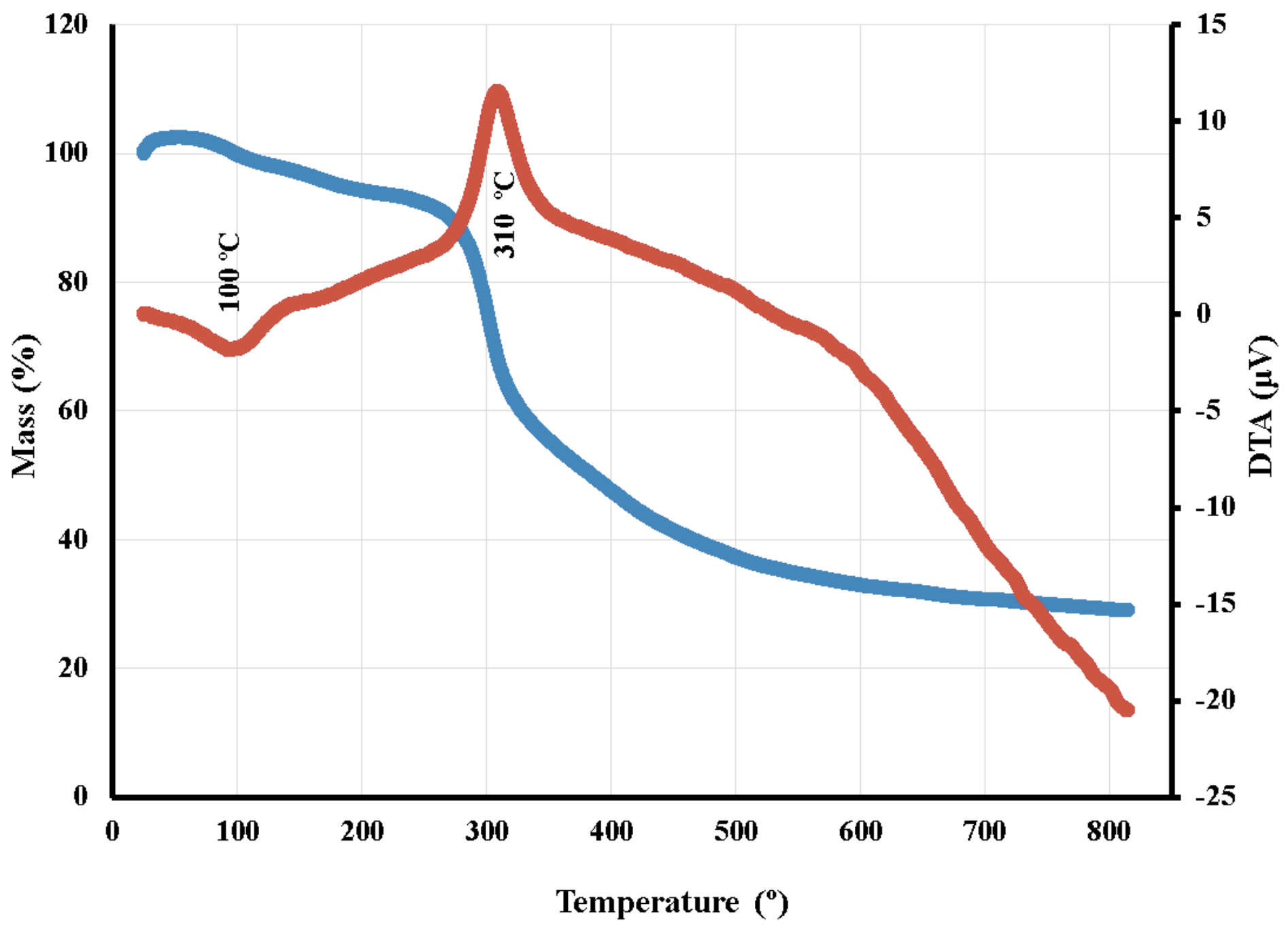

Figure 3

TG-DTA curves of Epy-Chit-cin 


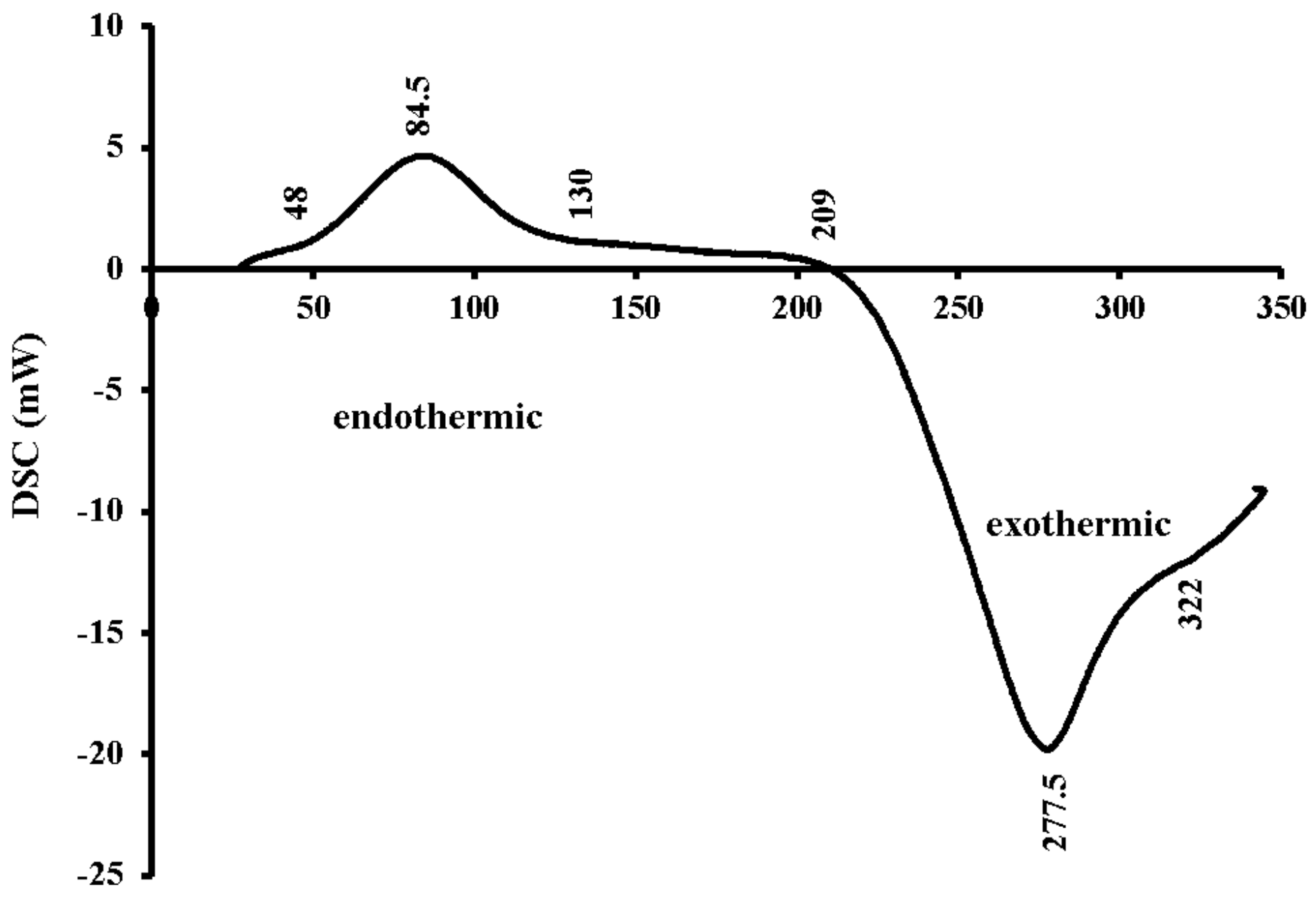

Temperature $\left({ }^{\circ} \mathrm{C}\right)$

Figure 4

DSC thermogram of Epy-Chit-cin 


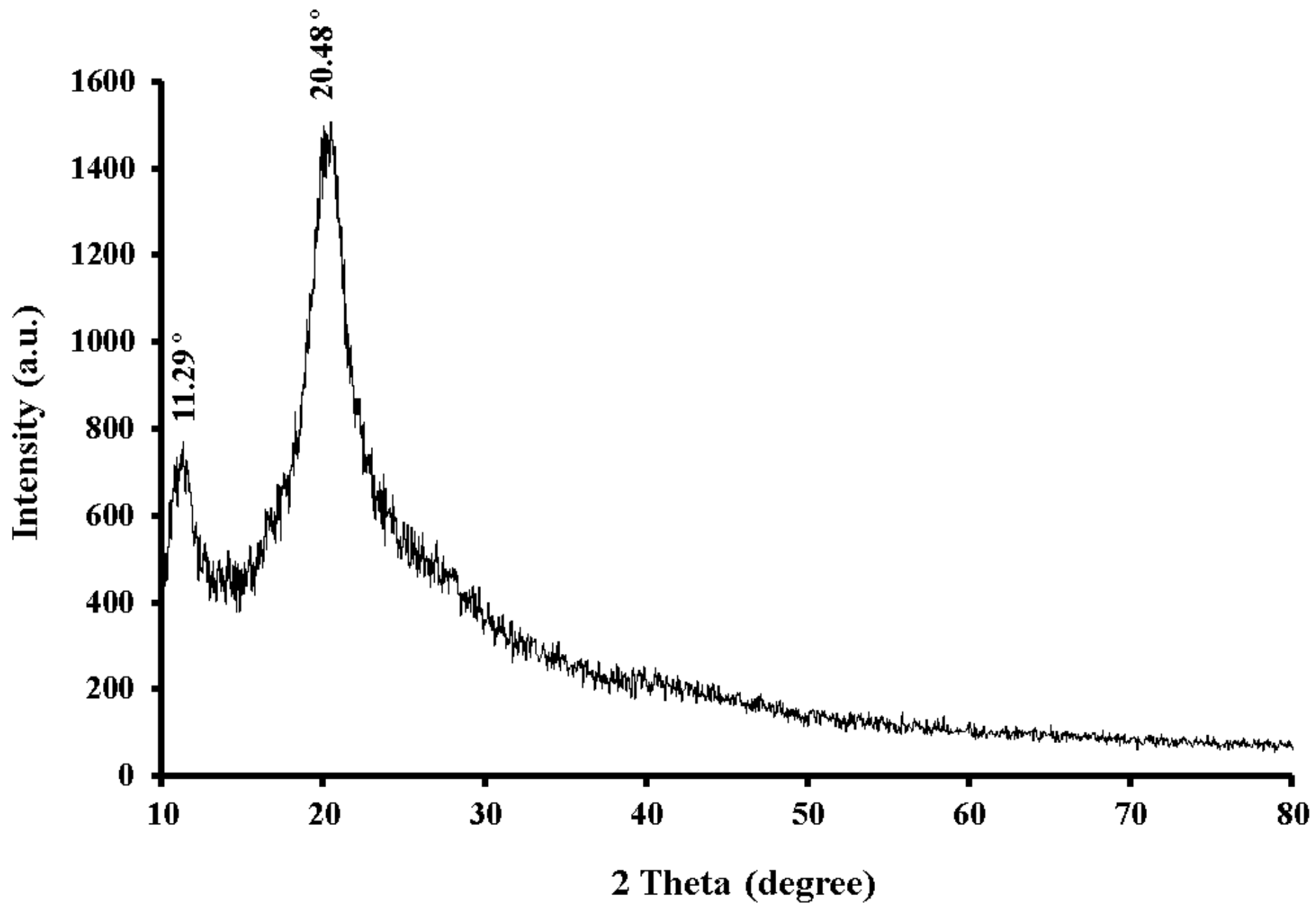

Figure 5

XRD pattern of Epy-Chit-cin 


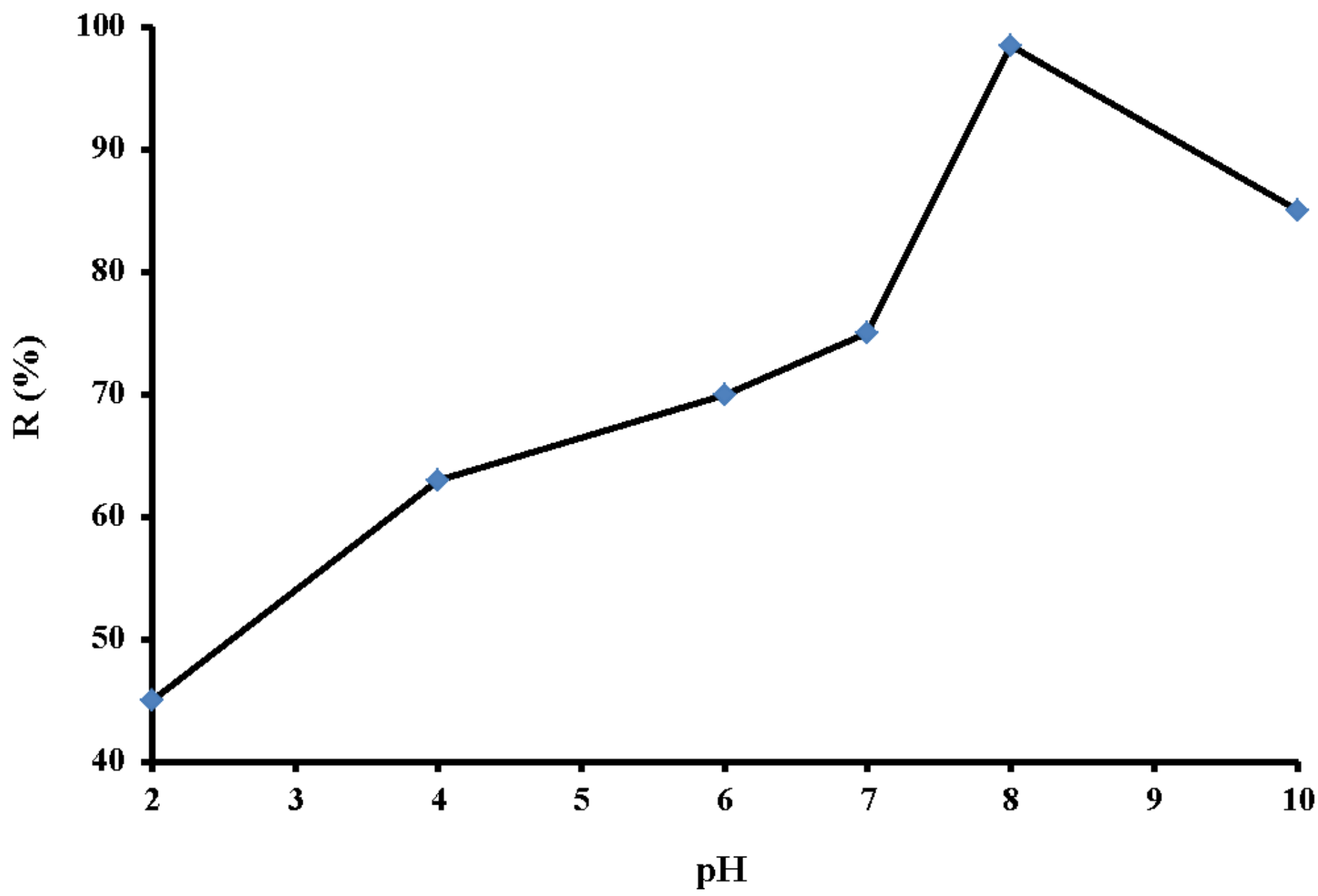

Figure 6

Effect of initial $\mathrm{pH}$ on removal percentage of MG 


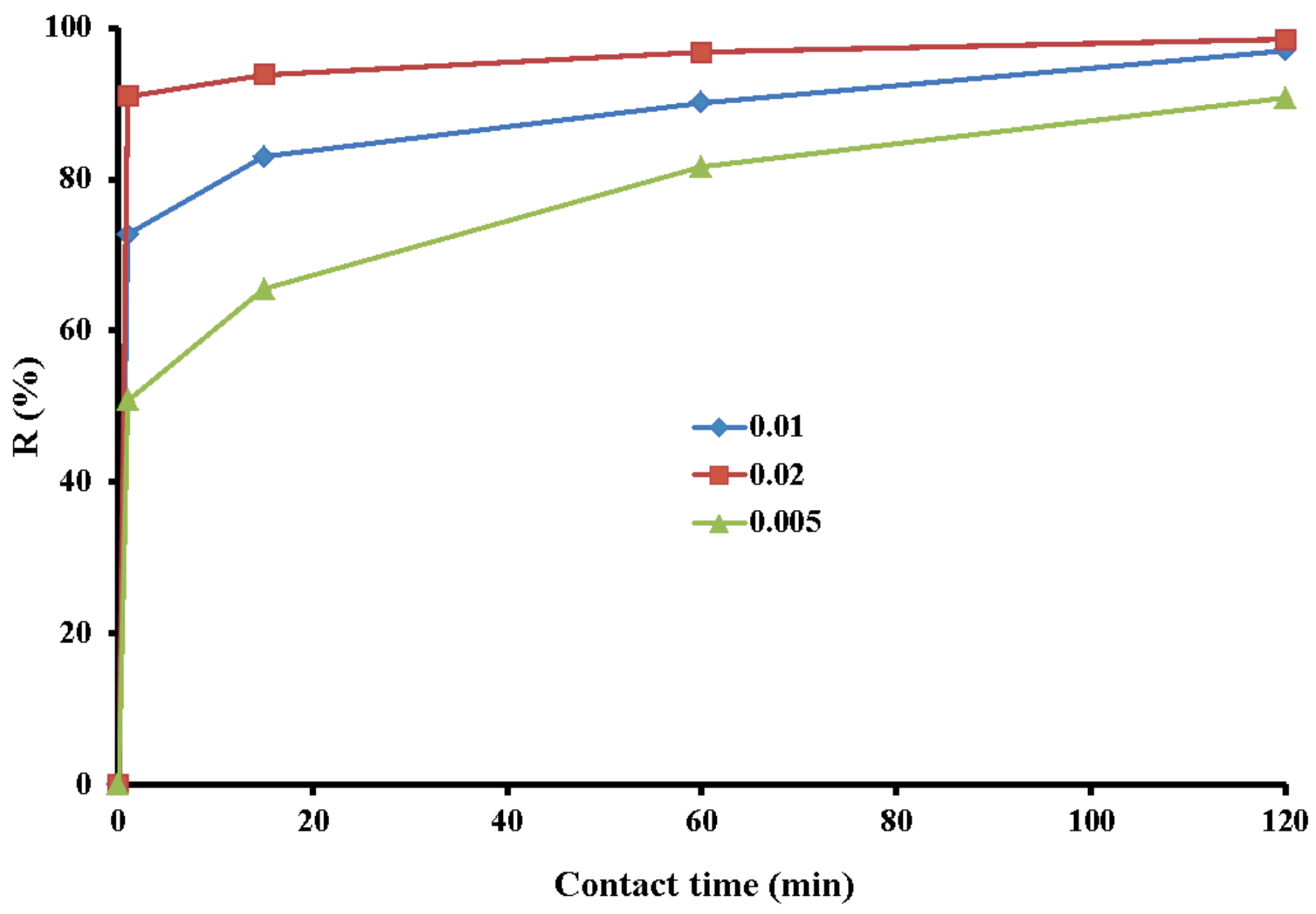

Figure 7

Effect of adsorbent dosage and contact time on the percentage removal of MG

\section{Supplementary Files}

This is a list of supplementary files associated with this preprint. Click to download.

- Scheme1.png 